\title{
Student perception of topic difficulty: Lecture capture in higher education
}

\author{
Patrick McCunn and Genevieve Newton \\ University of Guelph, Canada
}

Perception of topic difficulty is a likely predictor of lecture capture video use, as student perception of difficulty has been shown to affect a variety of outcomes in academic settings. This study measured the relationship between perceived difficulty and the use of lecture capture technology in a second year biochemistry course while additionally taking into account student learning approaches, comfort with technology, gender and performance outcomes. In several analyses, it was found that a higher perceived level of difficulty was associated with an increased number of video accessions, although this relationship was not consistent across all topics. As well, it was found that surface learning approach score and gender were significantly associated with the number of accessions of lecture capture videos, while deep approach score, course grade, and level of comfort with technology were not. This study confirms that student use of lecture capture is related to their perception of topic difficulty, and demonstrates that student characteristics also influence lecture capture behaviour. Although the strength of our observed associations were weak, the level of content difficulty may be an important factor to consider when deciding when to use lecture videos as learning resources in higher education.

\section{Introduction}

The use of multimedia technology in an educational setting has increased dramatically in recent years as it becomes more accessible and affordable (Copley, 2007; Le, Joordens, Chrysostomou, \& Grinnell, 2010; Parson, Reddy, Wood, \& Senior, 2009). The term lecture capture refers to the multimedia recording of classroom lectures that are subsequently made available digitally for the use of students. While this term may refer to a variety of lecture recording contexts, for the purposes of this article, the term lecture capture will be used to describe recordings that were made from a live lecture delivered to a group of students enrolled in a given course, which were then provided in a digital format to only those students. These recordings may be audio, video, or both, and are often combined with other instructional tools such as lecture slides, in an attempt to enhance educational instruction. Specifically, in undergraduate learning environments, lecture capture has become widely used as a tool to both substitute and supplement face-to-face classroom time (Euzent, Martin, \& Moskal, 2011; Newlin \& Wang, 2002). This technology aims to provide students with ondemand access to lecture content which caters to that student's preferences and limitations (Bennett \& Glover, 2008; Copley, 2007; Leadbeater, Shuttleworth, Couperthwaite, \& Nightingale, 2013). In the present study, the term lecture capture refers to digital video recordings of live lectures.

The rising popularity of lecture capture is not surprising, given the widespread use of technology by the current generation of students. Youth today spend several hours using digital technology daily (Jenkins et al., 2009), with incoming university students labeled as "digital natives" who are experienced and comfortable with technology such as computers, cell phones, and other digital tools (Prensky, 2001). As use of this technology increases, so too does the research into appropriate technological and pedagogical applications for lecture capture. As reviewed in Newton, Tucker, Dawson, \& Currie (2014), numerous benefits have been cited, including increased student performance (Boster et al., 2006; Parson et al., 2009), increased access to content (Bennett \& Glover, 2008; Copley, 2007; Leadbeater et al., 2013) increased student satisfaction (Bennett \& Glover, 2008; Bongey, Cizadlo, \& Kalnbach, 2006; Euzent et al., 2011; Vajoczki, Watt, Marquis, Liao, \& Vine, 2011), and increased motivation and self-efficacy (Bolliger, Supankorn, \& Boggs, 2010; Chester, Buntine, Hammond, \& Atkinson, 2011). On the other hand, in some instances the use of lecture capture has been linked to decreased perception of the importance of attendance (Brotherton \& Abowd, 2004; Chester, Buntine et al., 2011; Traphagan, Kuscera, \& Kishi, 2010) and encouragement of surface learning approaches (Leadbeater et al., 2013). Despite the breadth of literature regarding the use of lecture capture in a 
higher education setting, little research has been done regarding the use of lecture capture as related to a students' perceived level of difficulty of a topic. It has been shown that the way people approach a task is influenced by the perceived level of difficulty of that task (Karabenick \& Youssef, 1968). Indeed, these perceptions extend into the educational forum as perceived course difficulty has been shown to influence behaviours such as performance approach and performance avoidance (Darnon, Butera, Mugny, Quiamzade, \& Hulleman, 2009; Heikkilä \& Lonka, 2006). In addition, when a course is considered conceptually difficult, students have shown a preference for traditional instructional methods over supplements such as lecture capture (Bassili, 2008). Student characteristics such as gender and comfort with technology may further influence the use of this technology (Bolliger et al., 2010; Bassili, 2006; Wiese \& Newton, 2014). Following these findings, it is expected that perception of topic difficulty is a likely predictor of lecture capture use, which may be further influenced by a variety of student characteristics. Therefore, this study sought to determine the relationship between perceived level of difficulty and the use of lecture capture technology in a second year biochemistry course, while additionally taking into account student learning approaches, comfort with technology, gender and course performance.

\section{Background}

Considerable research has been conducted on the effect of multiple variables such as attitude, epistemological beliefs and perceived difficulty on student's ability to learn. These variables often interact in a complex way and are highly dependent on the individual. As students enter a higher education setting, the perceived level of difficulty becomes increasingly important, and at times is the most important factor influencing their behaviour (Ting \& Lee, 2012). Some students show an affinity for increased difficulty in their education while others show avoidance (Inoue, 2007; Ting \& Lee, 2012). Furthermore, the way in which a student approaches a difficult task varies greatly, and this approach has been shown to be influenced by gender, motivation, and learning approaches (Bolliger et al., 2010).

Many psychological studies have attempted to understand the effect of perceived level of difficulty of a task on eventual outcomes. These studies have shown that performance expectancies (Darnon et al., 2009), perceived importance (Williams \& Teasdale, 1982), and motivation (Karabenick \& Youssef, 1968) all change measurably in relation to the perceived difficulty. This weighing of importance extends heavily to education, as students will adopt different learning approaches when faced with content perceived to be highly difficult. Students with high academic competency expectancies tend to adopt performance-approach strategies to learning which have been positively linked with better exam performance, whereas students viewing content as too complex adopt performance-avoidance strategies to learning, leading to poor exam performance (Darnon et al, 2009). Furthermore, students who adopt these performance-approach strategies perform better and experience less performance deterioration as task difficulty increases than students who adopt performance-avoidance strategies (Capa, Audiffren, \& Ragot, 2008). These psychological differences lead to differing use of instructional material such as lecture capture, with research suggesting that students who perceive subject matter to be difficult prefer face-to-face instruction rather than online or supplemental instruction (Bassili, 2008).

The use of lecture capture itself has been shown to be dependent on many student characteristics, with learning approach often being a dominant characteristic. Several studies have shown that students who adopt a deeper learning approach tend to use lecture capture as a tool for review and a way to supplement face-toface learning (Le, Joordens, Chrysostomou, \& Grinnell, 2010; Vajoczki et al., 2011; Wiese \& Newton, 2013). These students also have a tendency to access lecture capture throughout the extent of the course. Students who adopt a surface learning approach tend to use lecture capture as a substitute for face-to-face learning and often only access the multimedia directly before quizzes, exams, or assignments (Vajoczki et al., 2011; Wiese \& Newton, 2013). Likewise, a student's comfort with technology has been shown to influence lecture capture accession, as students who experience anxiety over Internet and multimedia technology are less likely to view online lectures (Bassili, 2006; Brotherton \& Abowd, 2004). Gender also has an influence on lecture capture use, with males being more likely to use lecture capture as a means of catching up on missed classes (Brady, 
Wong, \& Newton, 2013), while females are more likely to access lecture capture content based on relevance (Bolliger et al., 2010).

Much of the research on lecture capture use in education uses a student's eventual course grade as a measure of success or failure. This data is variable, with studies showing lecture capture use to have a positive correlation (Boster et al., 2006; Boster et al., 2007; Traphagan et al., 2010), negative correlation (Le et al., 2010) and no correlation (Brotherton \& Abowd, 2004; Dupagne, Millette. \& Grinfeder, 2009; Euzent et al., 2011; Leadbeater et al., 2013; Ron, Denys, \& Wideman, 2011) to higher course grades, emphasising the importance of how lecture capture is used, rather than if it is used. Students who use lecture capture videos as supplemental learning tools tend to have higher grades and better comprehension of material (Le et al., 2010). In addition, students who use various options, such as pause and seek, when reviewing material show higher surface learning scores, more memorisation and lower overall comprehension whereas students who watch lecture capture continuously tend to correlate positively with deeper learning scores, higher comprehension, and better grades (Le et al., 2010).

Despite the increase in research on the use of lecture capture in an educational setting, there has been little investigation of the effect of student perception of the level of topic difficulty. This study sought to address this gap by examining the accession of lecture capture videos by students in a second year biochemistry course at the University of Guelph-Humber. Lecture capture accessions were tracked and analysed in an attempt to examine the following research questions:

(1) Are there differences in the frequency with which students access lecture capture videos with different perceived levels of topic difficulty?

(2) Is the frequency with which students access lecture capture videos with different perceived levels of topic difficulty associated with student learning approach, level of comfort with technology, gender, or grade?

\section{Research method}

\section{Subjects}

All students attending the Fall 2012 and Winter 2013 sections of KIN 2070 Biochemistry \& Metabolism II in the University of Guelph Humber in Canada were invited to participate in the present study. Data was collected from 87 students (38 male and 49 female) with a mean age of $21.49 \pm 4.51$ yrs.

\section{Lecture capture accession}

Lecture capture accession was tracked through the course management software. As it was possible to open a video multiple times simultaneously, accessions were separated based on a minimum of 10 seconds before a subsequent accession.

\section{Revised two factor study process questionnaire}

All students who consented to being a part of the study completed the revised two-factor study process questionnaire (R-SPQ-2F) (Biggs, Kember, \& Leung, 2001) at the end of the semester $(n=87)$. The R-SPQ$2 \mathrm{~F}$ questionnaire is designed to measure whether students take a deep or surface approach to learning. It was initially developed as the study process questionnaire (SPQ) (Biggs, 1987). The revised version of the questionnaire consists of 20 questions, with 10 items representing each approach, and it has four sub-scales that describe motive and strategy (Biggs et al., 2001). However, the R-SPQ-2F has recently been shown to best describe the two factors of deep and surface as measured by their 10 corresponding items (Justicia, Pichardo, Cano, Berben, \& De la Fuente, 2008), so these are the only variables that will be considered in this investigation. 


\section{Surveys}

Demographic data as well as the R-SPQ-2F was collected through FluidSurveys, an online program, at the end of the semester. The course was divided into 10 modules: Glycogenesis, Glycogenolysis, Glycolysis, Citric acid cycle, ETC, Gluconeogenesis, Lipolysis, Lipogenesis, Protein metabolism, and Metabolic integration. Students were asked to rank their perceived level of difficulty for each module on a scale of 10 (with 10 being the maximum difficulty). In addition students were asked to rank their comfort with technology using a slider response on a scale of 100 (with 100 being the maximum comfort).

\section{Statistical analysis}

There were two confounding issues that were taken into account when analysing this data. First, among the students who consented to participate in the study $(n=87)$, analysis of activity in the course management software showed that not all of them accessed the lecture videos $(n=15)$, so data from participants who did not access any videos throughout the semester was removed from the analysis. Second, the duration of lecture video availability for viewing varied depending on when in the semester the lecture was presented. However, there was an approximate 2-week period between the end of lectures (by which time all lecture videos were available) and the final exam, which provided a reasonable time frame within which to analyse data. It is important to note that the final exam for the course was cumulative, with all captured material being represented by multiple-choice and short-answer questions. So, to eliminate the effect of including non-users in the analysis and to minimise the effect of variation in the length of time for which videos were accessible to students, data was grouped into two separate models: ((i) users only across the entire semester) $(n=72)$, and (ii) users only, looking at the accession of lecture capture from the time classes ended to the time of the exam, described as the pre-exam period $(n=65)$. We believe the second model provides the most accurate representation of the relationship between the accession of lecture capture videos and the perceived level of topic

difficulty.

Data was analysed using SPSS version 21. Data was analysed in two ways. First, the relationship between perceived difficulty and video accessions for each module (10 in total) as individual units was determined. To do this, simple linear regressions were performed analysing the relationship between perceived difficulty of each module as the independent variable and the number of lecture video accessions for that module as the dependent variable. Second, the overall relationship between perceived difficulty and accessions was determined, with modules combined in the analysis rather than being considered individually. For this analysis, each topic was defined by three numbers: the module number (randomly assigned as 1-10 across the eight modules), the level of difficulty assigned by the student, and the number of views of the video by each student. The dependent variable was the number of views, and the two independent variables were module and level of difficulty. As well, user characteristics were considered as additional independent variables in several secondary analyses. To do these analyses, multiple linear regressions were performed with the following combinations of independent variables: (i) perceived difficulty and module, ii) perceived difficulty, module, and deep approach score, ii) perceived difficulty, module, and surface approach score, iv) perceived difficulty, module, and gender, v) perceived difficulty, module, and course grade, vi) perceived difficulty, module, and comfort with technology. Significance was set at $p \leq 0.05$, while a statistical trend was defined as $p \leq 0.10$.

\section{Results}

\section{Student characteristics}

Mean demographic characteristics of the students in this study are summarised in Table 1 . Table 2 summarises the mean perceived difficulty for each module, and the mean number of video accessions per student. 
Table 1

Summary of student characteristics. Data is presented as mean \pm SEM.

\begin{tabular}{lcccccc}
\hline Gender & $\begin{array}{c}\text { No. of } \\
\text { participants }\end{array}$ & Age & $\begin{array}{c}\text { Deep } \\
\text { approach } \\
\text { score }\end{array}$ & $\begin{array}{c}\text { Surface } \\
\text { approach } \\
\text { score }\end{array}$ & $\begin{array}{c}\text { Final course } \\
\text { grade (\%) }\end{array}$ & $\begin{array}{c}\text { Comfort with } \\
\text { technology }\end{array}$ \\
\hline Male & 38 & $21.68 \pm 2.21$ & $27.75 \pm 5.51$ & $25.89 \pm 6.49$ & $76.89 \pm 10.11$ & $84.14 \pm 13.94$ \\
Female & 49 & $21.37 \pm 5.60$ & $26.08 \pm 5.75$ & $24.70 \pm 5.99$ & $75.70 \pm 8.25$ & $76.96 \pm 24.94$ \\
Total & 87 & $21.49 \pm 4.51$ & $26.78 \pm 5.71$ & $25.20 \pm 6.23$ & $76.20 \pm 9.09$ & $80.00 \pm 21.29$ \\
\hline
\end{tabular}

Table 2

Perceived difficulty and number of video accessions for each module. Data is presented as mean \pm SEM.

\begin{tabular}{lcc}
\hline Module & Perceived difficulty & No. of accessions \\
\hline Glycolysis & $3.98 \pm 2.40$ & $1.1977 \pm 1.85$ \\
ETC & $4.14 \pm 2.41$ & $1.6163 \pm 2.11$ \\
Glycogenesis & $4.43 \pm 1.96$ & $1.0233 \pm 1.80$ \\
Citric acid cycle & $4.51 \pm 2.48$ & $1.0000 \pm 1.91$ \\
Glycogenolysis & $4.70 \pm 2.05$ & $0.7209 \pm 1.17$ \\
Gluconeogenesis & $5.03 \pm 1.89$ & $1.3605 \pm 1.80$ \\
Lipolysis & $5.14 \pm 1.97$ & $1.8488 \pm 2.17$ \\
Lipogenesis & $5.43 \pm 2.12$ & $1.0581 \pm 1.28$ \\
Protein metabolism & $6.79 \pm 2.08$ & $3.2093 \pm 3.36$ \\
Metabolic integration & $6.79 \pm 2.01$ & $1.7674 \pm 2.00$ \\
\hline
\end{tabular}

\section{Linear regression}

Linear regressions were conducted to investigate the associations between the perceived level of difficulty and the number of lecture capture video accessions for each module (Table 3). It was found that within the users only/pre-exam model, the perceived level of difficulty was significantly associated with the number of accessions of lecture capture videos in the metabolic integration module $(p=0.017)$. Trends towards statistical significance were found for the following modules: protein metabolism module (users only/preexam model [ $p=0.062]$ ), and glycogenesis (users only/pre-exam model [ $\mathrm{p}=0.077]$ ). All analyses showed direct associations.

\section{Multiple linear regressions}

In the model of users only across the entire semester, each combination of independent variables (i-vi) significantly predicted the number of accessions of lecture capture $(p \leq 0.001)$, with direct associations (Table 4). The following independent variables showed significance within each combination of independent variables described previously: (i) module, (ii) module, (iii) module, perceived difficulty, and surface approach score, (iv) module, perceived difficulty, and gender, (v) module and perceived difficulty, (vi) module and comfort with technology. The following independent variables indicated trends within each regression: (i) perceived difficulty, (ii) perceived difficulty. Direct associations were found for module, perceived difficulty, grade and comfort with technology. Indirect associations were found for deep approach 
score, surface approach score, and gender. In the model of users only during the pre-exam period, each combination of independent variables (i-vi) similarly significantly predicted the number of accessions of lecture capture $(p \leq 0.001)$, with direct associations (Table 5). All independent variables within each regression showed significance except the following: (ii) deep approach score, (v) grade, (vi) comfort with technology. Direct associations were found for module, perceived difficulty, and comfort with technology. Indirect associations were found for deep approach score, surface approach score, gender and grade.

Table 3

Associations between perceived difficulty and video accessions for each module

\begin{tabular}{lcccccc}
\hline \multirow{2}{*}{ Module } & \multicolumn{3}{c}{ Users only } & \multicolumn{3}{c}{ Pre-exam, users only } \\
\cline { 2 - 7 } & $\mathrm{R}$ & $\mathrm{R}^{2}$ & $\mathrm{p}$ & $\mathrm{R}$ & $\mathrm{R}^{2}$ & $\mathrm{p}$ \\
\hline Glycogenesis & 0.112 & 0.012 & 0.353 & 0.222 & 0.049 & 0.077 \\
Glycogenolysis & 0.135 & 0.018 & 0.261 & 0.148 & 0.022 & 0.242 \\
Glycolysis & 0.189 & 0.036 & 0.114 & 0.149 & 0.022 & 0.239 \\
Citric acid cycle & 0.104 & 0.011 & 0.386 & 0.012 & 0.000 & 0.926 \\
ETC & 0.052 & 0.003 & 0.667 & 0.026 & 0.001 & 0.838 \\
Gluconeogenesis & 0.090 & 0.008 & 0.453 & 0.134 & 0.018 & 0.291 \\
Lipolysis & 0.176 & 0.031 & 0.142 & 0.200 & 0.040 & 0.113 \\
Lipogenesis & 0.153 & 0.023 & 0.203 & 0.207 & 0.043 & 0.101 \\
Protein metabolism & 0.123 & 0.015 & 0.309 & 0.234 & 0.055 & 0.062 \\
Metabolic integration & 0.242 & 0.059 & $0.042^{*}$ & 0.297 & 0.088 & 0.017 \\
\hline
\end{tabular}

Table 4

Associations between video accessions and multiple independent variables for lecture capture users only across the entire semester

\begin{tabular}{|c|c|c|c|c|c|c|}
\hline \multirow{2}{*}{ Independent variables } & \multirow[b]{2}{*}{$R$} & \multirow{2}{*}{$R^{2}$} & \multirow[b]{2}{*}{$p$} & \multicolumn{3}{|c|}{ Individual $p$ values } \\
\hline & & & & Independent variable & $\beta$ & $p$ \\
\hline \multirow{2}{*}{ Perceived difficulty, module } & \multirow{2}{*}{0.270} & \multirow{2}{*}{0.073} & \multirow{2}{*}{0.000} & Perceived difficulty & 0.116 & 0.002 \\
\hline & & & & Module & 0.156 & 0.000 \\
\hline \multirow{3}{*}{$\begin{array}{l}\text { Perceived difficulty, module, } \\
\text { deep approach score }\end{array}$} & \multirow{3}{*}{0.272} & \multirow{3}{*}{0.074} & \multirow{3}{*}{0.000} & Perceived difficulty & 0.113 & 0.002 \\
\hline & & & & Module & 0.156 & 0.000 \\
\hline & & & & Deep approach score & -0.012 & 0.410 \\
\hline \multirow{3}{*}{$\begin{array}{l}\text { Perceived difficulty, module, } \\
\text { surface approach score }\end{array}$} & \multirow{3}{*}{0.302} & \multirow{3}{*}{0.091} & \multirow{3}{*}{0.000} & Perceived difficulty & 0.122 & 0.001 \\
\hline & & & & Module & 0.154 & 0.000 \\
\hline & & & & Surface approach score & -0.048 & 0.000 \\
\hline \multirow{3}{*}{$\begin{array}{l}\text { Perceived difficulty, module, } \\
\text { gender }\end{array}$} & \multirow{3}{*}{0.311} & \multirow{3}{*}{0.097} & \multirow{3}{*}{0.000} & Perceived difficulty & 0.114 & 0.002 \\
\hline & & & & Module & 0.156 & 0.000 \\
\hline & & & & Gender & -0.687 & 0.000 \\
\hline \multirow{3}{*}{$\begin{array}{l}\text { Perceived difficulty, module, } \\
\text { grade }\end{array}$} & \multirow{3}{*}{0.277} & \multirow{3}{*}{0.077} & \multirow{4}{*}{0.000} & Perceived difficulty & 0.118 & 0.002 \\
\hline & & & & Module & 0.156 & 0.000 \\
\hline & & & & Grade & -0.009 & 0.380 \\
\hline \multirow{3}{*}{$\begin{array}{l}\text { Perceived difficulty, module, } \\
\text { comfort with technology }\end{array}$} & \multirow{3}{*}{0.272} & \multirow{3}{*}{0.074} & & Perceived difficulty & 0.040 & 0.002 \\
\hline & & & \multirow{2}{*}{0.000} & Module & 0.139 & 0.000 \\
\hline & & & & $\begin{array}{l}\text { Comfort with } \\
\text { technology }\end{array}$ & 0.010 & 0.353 \\
\hline
\end{tabular}


Table 5

Associations between video accessions and multiple independent variables for lecture capture users only across the pre-exam period

\begin{tabular}{|c|c|c|c|c|c|c|}
\hline \multirow{2}{*}{ Independent variables } & \multirow{2}{*}{$R$} & \multirow{2}{*}{$R^{2}$} & \multirow[b]{2}{*}{$p$} & \multicolumn{3}{|c|}{ Individual $p$ values } \\
\hline & & & & Independent variable & $\beta$ & $p$ \\
\hline \multirow{2}{*}{ Perceived difficulty, module } & \multirow{2}{*}{0.367} & \multirow{2}{*}{0.135} & \multirow{2}{*}{0.000} & Perceived difficulty & 0.166 & 0.001 \\
\hline & & & & Module & 0.185 & 0.000 \\
\hline \multirow{3}{*}{$\begin{array}{l}\text { Perceived difficulty, module, deep } \\
\text { approach score }\end{array}$} & \multirow{3}{*}{0.368} & \multirow{3}{*}{0.136} & \multirow{3}{*}{0.000} & Perceived difficulty & 0.164 & 0.000 \\
\hline & & & & Module & 0.186 & 0.000 \\
\hline & & & & Deep approach score & -0.011 & 0.427 \\
\hline \multirow{3}{*}{$\begin{array}{l}\text { Perceived difficulty, module, } \\
\text { surface approach score }\end{array}$} & \multirow{3}{*}{0.375} & \multirow{3}{*}{0.141} & \multirow{3}{*}{0.000} & Perceived difficulty & 0.169 & 0.000 \\
\hline & & & & Module & 0.184 & 0.000 \\
\hline & & & & Surface approach score & -0.026 & 0.033 \\
\hline \multirow{3}{*}{$\begin{array}{l}\text { Perceived difficulty, module, } \\
\text { gender }\end{array}$} & \multirow{3}{*}{0.389} & \multirow{3}{*}{0.151} & \multirow{3}{*}{0.000} & Perceived difficulty & 0.169 & 0.000 \\
\hline & & & & Module & 0.184 & 0.000 \\
\hline & & & & Gender & -0.529 & 0.000 \\
\hline \multirow{3}{*}{$\begin{array}{l}\text { Perceived difficulty, module, } \\
\text { grade }\end{array}$} & \multirow{3}{*}{0.375} & \multirow{3}{*}{0.141} & \multirow{3}{*}{0.000} & Perceived difficulty & 0.172 & 0.000 \\
\hline & & & & Module & 0.184 & 0.000 \\
\hline & & & & Grade & -0.002 & 0.862 \\
\hline \multirow{3}{*}{$\begin{array}{l}\text { Perceived difficulty, module, } \\
\text { comfort with technology }\end{array}$} & \multirow{3}{*}{0.367} & \multirow{3}{*}{0.135} & \multirow{3}{*}{0.000} & Perceived difficulty & 0.166 & 0.000 \\
\hline & & & & Module & 0.185 & 0.000 \\
\hline & & & & $\begin{array}{l}\text { Comfort with } \\
\text { technology }\end{array}$ & 0.000 & 0.992 \\
\hline
\end{tabular}

\section{Discussion}

This study sought to examine the relationship between perceived topic difficulty and accession of lecture capture videos by students in a second year biochemistry course at the University of Guelph-Humber as a primary objective. Secondarily, additional relationships with variables including student approach to learning, comfort with technology, gender, and course grade were also considered. In several analyses, it was found that a higher perceived level of difficulty was associated with an increased number of video accessions, although this relationship was not consistent across all modules independently. As well, it was found that surface learning approach score and gender were significantly associated with the number of accessions of lecture capture content, while deep approach score, course grade, and level of comfort with technology were not.

Regarding the primary objective of this study, a direct relationship was observed between perceived difficulty and the number of lecture video accessions in the most relevant analyses. Data was first analysed by looking at each module (or topic) independently, and here, there were few cases showing significant associations. This suggests that the perceived level of difficulty is not a strong independent predictor of the number of accessions of lecture capture material, a finding that is not surprising when considering that students with different learning habits are known to approach difficult tasks in different ways (Inoue, 2007; Ting \& Lee, 2012). Thus, it would be expected that the perceived level of difficulty, on its own, would not significantly predict the number of accessions of lecture capture content for all students. However, it is likely more appropriate to consider these relationships across the course as a whole, rather than considering each topic independently. Here, when the combined relationship was determined, it was found that the perceived difficulty was a significant predictor of the number of accessions of lecture capture content in both models with direct associations. Thus, it is concluded that over the entirety of the course, students accessed modules with a higher perceived level of difficulty more often than those deemed less difficult. It should be noted, however, that while a relationship was found, in both models it showed a weak correlation. 
A secondary objective of this study was to consider the relationship between perceived topic difficulty and accession of lecture capture videos as related to student learning approach. We found that student surface learning scores were significantly associated with accession of lecture capture content. In both models, this was a negative correlation, with an increased surface approach score predicting a lower mean number of video views. This is consistent with the literature on learning approaches, as surface learners have been shown to be less likely to access multimedia and supplemental instructional sources (Jelfs \& Colbourn, 2002; Vajoczki et al., 2011). Furthermore, surface learners are more likely to adopt performance-avoidance strategies to difficult tasks (Darnon et al., 2009). These characteristics of surface learners may lead them to be less likely to access lecture capture videos pertaining to modules they perceived to be more difficult.

A further secondary objective of this study was to consider the relationship between perceived topic difficulty and accession of lecture capture videos as related to student gender. In both models, gender was significantly associated with the number of lecture capture accessions. Based on the assignment of gender in our statistical analysis, with males being assigned (1) and females assigned (2), the negative correlation that we observed indicates that males were more likely to access this technology than females. Other studies have also shown differences in lecture capture behaviour between males and females. Males have been shown to be more likely to use lecture capture technology as a means of catching up on missed lectures than females, although with a longer period between the missed class and the lecture capture accession (Brady et al., 2013). Moreover, females have been shown to access supplemental material such as lecture capture based on perceived relevance (Bolliger et al., 2010), as well as to use lecture videos differently than males, such as to generate more comprehensive course notes (Wiese \& Newton, 2013). Our observation is therefore consistent with research demonstrating gender differences in the use of lecture capture technology.

There are several limitations to this study. First, no attempt was made to interpret the way in which students were using lecture capture modules to learn, nor to determine if students were using the lecture capture content to supplement face-to-face instruction or as a way to replace it. A student may have missed a class and accessed the lecture capture video as a means of introducing material whereas another student may have attended class and accessed the video as a means of reinforcing material. Both types of accession are counted the same in this study. Thus, while lecture capture accessions were tracked, to draw stronger conclusions it would be beneficial to also investigate the way in which a student used the material. For example, it would be interesting to determine if topics that were perceived as more difficult were also viewed more frequently in their entirety, rather than in selected sections, or if students were viewing videos to supplement what they learnt in class or to catch up on missed material. A second limitation to this investigation was that lecture videos were not all available for the same time period, meaning that the number of accessions would have likely been influenced by time independent of the perceived level of difficulty. To mitigate this issue, lecture capture accessions were tracked over the entire length of the course, as well as from the end of classes to the exam, a period of 2 weeks where all material had been presented. An increase in the $\mathrm{R}^{2}$ values for all multiple linear regressions was found when considering the pre-exam period only compared to the full course period, although the same associations were observed in both models. As well, it is important to note that there are several factors that influence behaviour associated with lecture capture that were not accounted for in this study. For example, lecture attendance is affected by the perceived educational value of the lecture, convenience and flexibility of the timing of the lecture, and social opportunities to exchange ideas and meet new friends (Gosper et al., 2008). Attendance is also determined by the qualities of the lecturer, rather than the availability of electronic material (Billings-Gagliardi \& Mazor, 2007). So, attendance in classes for which lecture capture videos are available is subject to influence by several variables, which could subsequently impact a student's use of lecture capture resources. Nonetheless, despite these limitations, the demonstration of a consistent - albeit weak - direct association between perceived difficulty and video accessions suggests that a relationship does exist.

In conclusion, this study fills an important gap in the literature regarding the relationship between a student's perceived level of topic difficulty and their use of lecture videos, although it is important to consider these findings in the context of the aforementioned limitations. We found that the perceived level of difficulty significantly predicted the number of accessions of lecture videos over the course as a whole, and we observed further relationships with student characteristics such as surface learning approach and gender. The 
findings of the present study are consistent with previous work that describes the effect of perceived level of task difficulty on eventual outcomes in academic settings, as well the breadth of research which demonstrates that multiple variables influence the way that students use lecture videos. These findings suggest that providing lecture capture to students in courses with a higher perception of topic difficulty, or for selected difficult topics within a course, may be an important consideration for teachers designing and teaching lecture based courses. While the strength of our observed associations were weak, the level of content difficulty may be an important factor to consider when to use lecture videos as learning resources in higher education.

\section{Acknowledgements}

The authors would like to thank Dr Michelle Edwards, data librarian at the University of Guelph for her help with the analysis of data.

\section{References}

Bassili, J. N. (2006). Promotion and prevention orientations in the choice to attend lectures or watch them online. Journal of Computer Assisted Learning, 22, 444-455. doi:10.1111/j.1365-2729.2006.00192.x

Bassili, J. N. (2008). Media richness and social norms in the choice to attend lectures or to watch them online. Journal of Educational Multimedia and Hypermedia, 17(4), 453-475.

Bennett, P. N., \& Glover, P. (2008). Video streaming: Implementation and evaluation in an undergraduate nursing program. Nurse Education Today, 28(2), 253-258. doi.org/10.1016/j.nedt.2007.04.005

Biggs, J. B. (1987). The study process questionnaire (SPQ): Manual. Melbourne: Australian Council For Educational Research.

Biggs, J. B., Kember, D., \& Leung, D. Y. P. (2001) The revised two-factor study process questionnaire: RSPQ-2F. British Journal of Educational Psychology, 71, 133-149. doi:10.1348/000709901158433

Billings-Gagliardi, S., \& Mazor, K. M. (2007). Student decisions about lecture attendance: Do electronic course materials matter? Journal of the Association of American Medical Colleges, 82, S73-S76. doi.org/10.1097/ACM.0b013e31813e651e

Bolliger, D. U., Supanakorn, S., \& Boggs, C. (2010). Impact of podcasting on student motivation in the online learning environment. Computers \& Education, 55(2), 714-722. doi.org/10.1016/j.compedu.2010.03.004

Bongey, S. B., Cizadlo, G., \& Kalnbach, L. (2006). Explorations in course-casting: Podcasts in higher education. Campus-Wide Information Systems, 23(5), 350-367..doi.org/10.1108/10650740610714107

Boster, F. J., Meyer, G., Roberto, A., Inge, C., \& Strom, R. (2006). Some effects of video streaming on educational achievement. Communication Education, 55, 46-62. doi:10.1080/03634520500343392

Boster, F. J., Meyer, G. S., Roberto, A. J., Lindsey, L., Smith, R., Inge, C., \& Strom, R. E.. (2007). The impact of video streaming on mathematics performance. Communication Education, 56, 134-144. doi:10.1080/03634520601071801

Brady, M., Wong, R., \& Newton, G. (2013). Characterization of catch-up behavior: Accession of lecture capture videos following student absenteeism. Education Sciences, 3(3), 344. doi.org/10.3390/educsci3030344

Brotherton, J. A., \& Abowd, G. D. (2004). Lessons learned from eClass. ACM Transactions on ComputerHuman Interaction, 11(2), 121-155. doi.org/10.1145/1005361.1005362

Capa, R. L., Audiffren, M., \& Ragot, S. (2008). The interactive effect of achievement motivation and task difficulty on mental effort. International Journal of Psychophysiology, 70(2), 144-150. doi.org/10.1016/j.ijpsycho.2008.06.007

Chester, A., Buntine, A., Hammond, K., \& Atkinson, L. (2011). Podcasting in education: Student attitudes, behaviour and self-efficacy. Educational Technology \& Society, 14(2), 236-247. Retrieved from http://www.ifets.info

Copley, J. (2007). Audio and video podcasts of lectures for campus-based students: Production and evaluation of student use. Innovations in Education and Teaching International, 44(4), 387-399. doi.org/10.1080/14703290701602805

Darnon, C., Butera, F., Mugny, G., Quiamzade, A., \& Hulleman, C. S. (2009). Too complex for me! Why do performance-approach and performance-avoidance goals predict exam performance? European Journal of 
Psychology of Education, 24(4), 423-434. doi.org/10.1007/BF03178759

Dupagne, M., Millette, D. M., \& Grinfeder, K. (2009). Effectiveness of video podcast use as a revision tool. Journalism \& Mass Communication Educator, 64(1), 54-70. doi.org/10.1177/107769580906400105

Euzent, P. J., Martin, T. L., \& Moskal, P. (2011). Teaching principles to the masses: Assessing student performance in lecture capture vs. face-to-face course delivery. doi:10.2139/ssrn.1868945

Gosper, M., Green, D., McNeil, M., Phillips, R., Preston, G., \& Woo, K. (2008) The impact of web-based lecture technologies on current and future practices in learning and teaching. Sydney: Australian Teaching and Learning Council. Retrieved from https://www.mq.edu.au/ltc/altc/wblt/research/report.html

Heikkilä, A., \& Lonka, K. (2006). Studying in higher education: student's approaches to learning, selfregulation, and cognitive strategies. Studies in Higher Education, 31,199-117. doi:10.1080/03075070500392433

Inoue, N. (2007). Why face a challenge? The reason behind intrinsically motivated students' spontaneous choice of challenging tasks. Learning and Individual Differences, 17(3), 251-259. doi.org/10.1016/j.lindif.2007.02.002

Jelfs, A., \& Colbourn, C. (2002). Do students' approaches to learning affect their perceptions of using computing and information technology? Journal of Educational Media, 27, 41-53. doi:10.1080/1358165020270104

Jenkins, H., Purushotma, R., Weigel, M., Clinton, K., \& Robison, A. J. (2009). Confronting the challenges of participatory culture: Media education for the 21st century. Chicago, IL: The John D. and Catherine T. MacArthur Foundation. Retrieved from http://digitallearning.macfound.org/atf/cf/\%7B7E45C7E0-A3E04B89-AC9C-E807E1B0AE4E\%7D/JENKINS_WHITE_PAPER.PDF

Justicia, F., Pichardo, M., Cano, F., Berben, A., \& De la Fuente, J. (2008). The revised two-factor study process questionnaire (R-SPQ-2F): Exploratory and confirmatory factor analyses at item level. European Journal of Psychology of Education, 23, 355-372. doi: 10.1007/BF03173004

Karabenick, S. A., \& Youssef, Z. I. (1968). Performance as a function of achievement motive level and perceived difficulty. Journal of Personality and Social Psychology, 10(4), 414-419. doi.org/10.1037/h0026735

Le, A., Joordens, S., Chrysostomou, S., \& Grinnell, R. (2010). Online lecture accessibility and its influence on performance in skills-based courses. Computers \& Education, 55, 313-319. doi:10.1016/j.compedu.2010.01.017

Leadbeater, W., Shuttleworth, T., Couperthwaite, J., \& Nightingale, K. P. (2013). Evaluating the use and impact of lecture recording in undergraduates: Evidence for distinct approaches by different groups of students. Computers \& Education, 61, 185-192. doi:10.1016/j.compedu.2012.09.011

Newlin, M. H., \& Wang, A. Y. (2002). Integrating technology and pedagogy: Web instruction and seven principles of undergraduate education. Teaching of Psychology, 29(4), 325-330. doi.org/10.1207/S15328023TOP2904_15

Newton, G., Tucker, T., Dawson, J., \& Currie, E. (2014). Use of lecture capture in higher education: Lessons from the trenches. Tech Trends, 58(2), 32-45. doi.org/10.1007/s11528-014-0735-8

Parson, V., Reddy, P., Wood, J., \& Senior, C. (2009). Educating an iPod generation: Undergraduate attitudes, experiences and understanding of vodcast and podcast use. Learning, Media and Technology, 34(3), 215228. doi.org/10.1080/17439880903141497

Prenksy, M. (2001). Digital natives, digital immigrants. On the Horizon, 9(5). Retrieved from http://www.marcprensky.com/writing/Prensky\%20\%20Digital\%20Natives,\%20Digital\%20Immigrants\%20-\%20Part1.pdf

Ron, O., Denys, L., \& Wideman, H. (2011). Lecture capture in large undergraduate classes: Student perceptions and academic performance. Internet and Higher Education, 14(4), 262-268. doi.org/10.1016/j.iheduc.2011.05.006

Ting, D. H., \& Lee, C. K. (2012). Understanding students' choice of electives and its implications. Studies in Higher Education, 37(3), 309-325. doi.org/10.1080/03075079.2010.512383

Traphagan, T., Kuscera, J. V., \& Kishi, K. (2010). Impact of class lecture webcasting on attendance and learning. Education Technology Research and Development, 58(1), 19-37. doi.org/10.1007/s11423-0099128-7

Vajoczki, S., Watt, S., Marquis, N., Liao, R., \& Vine, M. (2011). Students approach to learning and their use of lecture capture. Journal of Educational Multimedia and Hypermedia, 20(2), 195-214. Retrieved from 
http://www.aace.org/pubs/jemh/

Wiese, C., \& Newton, G. S. (2013). Use of lecture capture in undergraduate biological science education. Canadian Journal of the Scholarship of Teaching and Learning, 4(2), 12-31. doi.org/10.5206/cjsotlrcacea.2013.2.4

Williams, J. G., \& Teasdale, J. D. (1982). Facilitation and helplessness: The interaction of perceived difficulty and importance of a task. Behaviour Research and Therapy, 20(2), 161-171. doi.org/10.1016/00057967(82)90115-2

Corresponding author: Genevieve Newton, newton@uoguelph.ca

Australasian Journal of Educational Technology @ 2015.

Please cite as: Newton, G. \& McCunn, P. (2015). Student perception of topic difficulty: Lecture capture in higher education. Australasian Journal of Educational Technology, 31(3), 252-262. 